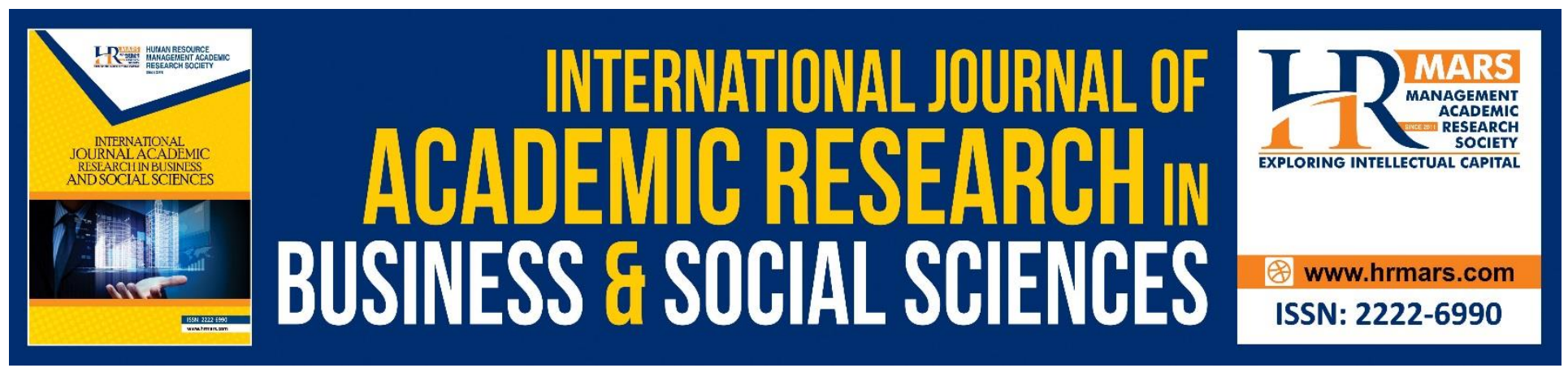

\title{
Forms of Play and How they Influence Acquisition of Numeracy Skills among Preschool Children in Kenya
}

Mary M. Muema, Peter Kibet Koech, Pamela Muriungi

To Link this Article: http://dx.doi.org/10.6007/IJARBSS/v8-i10/4780

DOI: $10.6007 /$ IJARBSS/v8-i10/4780

Received: 27 Sept 2018, Revised: 21 Oct 2018, Accepted: 26 Oct 2018

Published Online: 03 Nov 2018

In-Text Citation: (Muema, Koech, \& Muriungi, 2018)

To Cite this Article: Muema, M. M., Koech, P. K., \& Muriungi, P. (2018). Forms of Play and How they Influence Acquisition of Numeracy Skills among Preschool Children in Kenya. International Journal of Academic Research in Business and Social Sciences, 8(10), 799-812.

\section{Copyright: (C) 2018 The Author(s)}

Published by Human Resource Management Academic Research Society (www.hrmars.com)

This article is published under the Creative Commons Attribution (CC BY 4.0) license. Anyone may reproduce, distribute, translate and create derivative works of this article (for both commercial and non-commercial purposes), subject to full attribution to the original publication and authors. The full terms of this license may be seen

at: http://creativecommons.org/licences/by/4.0/legalcode

Vol. 8, No. 10, 2018, Pg. 799 - 812

http://hrmars.com/index.php/pages/detail/IJARBSS

JOURNAL HOMEPAGE

Full Terms \& Conditions of access and use can be found at http://hrmars.com/index.php/pages/detail/publication-ethics 


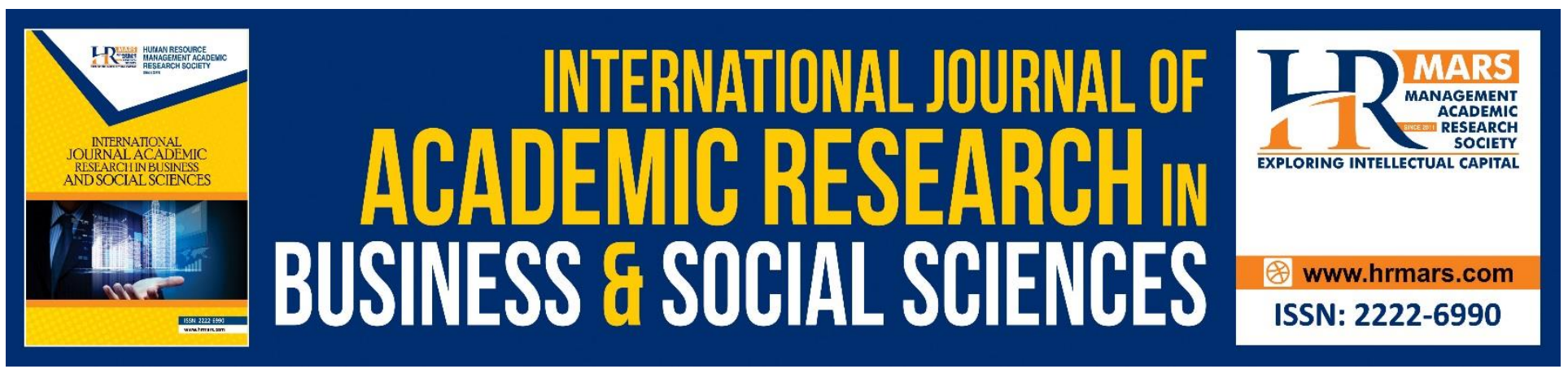

\title{
Forms of Play and How they Influence Acquisition of Numeracy Skills among Preschool Children in Kenya
}

\author{
${ }^{1}$ Mary M. Muema, ${ }^{2}$ Dr. Peter Kibet Koech, ${ }^{3}$ Dr. Pamela Muriungi \\ ${ }^{1}$ Early Childhood Education Lecturer, Machakos University, P.O. Box 136-90100, Machakos, \\ Kenya \\ ${ }^{2}$ Department of Early Childhood Education, Machakos University, P.0.136-90100, Machakos, \\ Kenya \\ ${ }^{3}$ Department of Early Childhood Education, Machakos University, P.0.136-90100, Machakos, \\ Kenya
}

\begin{abstract}
This study sought to underscore the influence of forms of play in the teaching of Mathematics, particularly acquisition of numeracy skills among children in preschool. The study was done among preschool children in Kenya. Its purpose was to assess the influence of forms of play on acquisition of numeracy skills in Early Childhood Development and Education (ECDE) centers. In this regard, while focusing on preschool institutions in Kenya the objective of the study was to find out forms of play and how they influence teaching of numeracy skills among preschool children in Kenya. The study utilized qualitative research design. The dependent variable for the study was the acquisition of numeracy skills among children in preschool institutions in Kenya, while independent variable is influence of form of play. The target population comprised of all preschool children and preschool teachers and head teachers in Kenya. The research instruments was piloted in two public and one private preschool institution that were not included in the study sample, but within the target population. The data collected was edited and coded according to themes that emanated from the research objective. Qualitative data was derived from open-ended responses received during interviews. The quantitative data was analyzed and presented using descriptive statistics such as frequency distribution, tables and percentages and also in narrative form. Qualitative data was presented in narrative form. Questionnaire, interview and observation schedules were used for data collection, while descriptive statistics was used in data analysis. The study established that (39\%) of ECDE teachers were not decided whether different forms of play enhanced acquisition of numeracy skills in ECDE Kathiani sub county. Thus, the study recommended that ECDE teachers should be made to understand the importance of play in enhancing acquisition of numeracy skills in ECDE centers. ECDE teachers should undertake further proficiency training on planning, organizing and delivering of content in ECDE
\end{abstract}


INTERNATIONAL JOURNAL OF ACADEMIC RESEARCH IN BUSINESS AND SOCIAL SCIENCES Vol. 8, No. 10, Oct. 2018, E-ISSN: 2222-6990 @ 2018 HRMARS

teaching and learning. It is expected that the findings of this study will contribute to the efforts towards early interventions to improve numeracy learning outcomes of among learners in Kenya. The study is of significant to the Ministry of Education, Kenya Institute of Curriculum Development, publishers and developers of early childhood education materials and teachers as well as owners and sponsors of ECDE institutions.

Key Words: Forms of Play, Preschool Children, Acquisition, Numeracy skills

\section{Introduction}

Play-based learning is described as a context for learning through which children organize and make sense of their social world as they actively engage with people and objects. Representation of young children's play allows them to explore, identify, negotiate, take risks and create meaning. The intellectual and cognitive benefits of playing have been well documented. Children who engage in quality play experiences are more likely to have well-developed numerical memory skills, and are able to regulate their behaviour, leading to enhanced school adjustment (Tina, 2005).

The children'splay is challenged by several forces including child labor and exploitation practices, war and neighborhood violence, and the limited resources available to children living in poverty. However, even those children who are lucky enough to have abundant available resources and who live in relative peace may not be receiving the full benefits of play. Many of these children are being raised in an increasingly rushed and pressured style that may limit the protective and numerical benefits they would gain from play (Syomwene, 2013).

In underscoring the importance of Early Childhood Development Education (ECDE), the Kenya Government through the Ministry of Education presented a sessional paper number one (1) 2005. This paper presents a policy framework for education training and research to develop a comprehensive ECDE policy paying attention to gender, vulnerable and disadvantaged children. This serves as evidence to the great concern that government has on the importance of education in the early years of the Kenyan child. The policy framework provides that early childhood education Programme include any types of educational Programme that server in early or formative years and is designed to improve later school performance. A growing nation needs healthy and active people who can perform day to day duties at various positions. One way of preparing such people is by having well organized play and physical activities from preschool years where foundation is laid. During preschool year's basic skills such as jumping, climbing, catching, dancing, singing, swimming, running and hoping can be developed (K.I.E, 2008).

According to Lain and Ganne, (2014) there is need for preschool teachers to understand the importance of play in order to provide appropriate methods for introducing numeracy activities. Also the preschool teachers should be aware of the needs of children and their different characteristics. This is because; the early childhood Programme provides learning though playing which is very important and special part of childhood whereby children develop numeracy skills like sharing, counting, capacity in filling and empting games among others. Play also helps children to develop problem solving skills like simple addition, matching and pairing number value, recognition of symbols and shapes of numbers and development of the child's eye- hand coordination. Play is seen as one of the miracles of childhood by means of which children discover things essential to their wellbeing. It is part of child's life and also as a necessary condition for development. It provides the child 
with a variety of essential experiences, sensory exploration, emotional and social experiences as well as experiences of mastery or achievement (Jean, 2006).

According to Gale (2005) the teacher should apply approaches that are child centered, motivating and sustains interest of all children. They should be provided with opportunities that stimulate them to play with sounds, rhythm, language, materials, space and ways to express their creative ideas so as to advance in physical and intellectual competence. This is because children's development of numeracy skills is affected by the nature of their early educational experiences; numeracy is essential skills for all children to develop. Without these experiences modern life becomes almost impossible. Yet, there is often disagreement about how teachers should approach this learning, and when aspects of it should be introduced to children. When people think of numeracy, often think of school rather than prior-to-school settings, and of formal teaching methods based on rote learning and memorization. From this perspective, it can sometimes be hard for us as early childhood educators to see how numeracy is relevant to our work in the very early years of a child's life. The temptation can be to leave numeracy for schools to worry about while parents and caregiver's direct efforts elsewhere. The foundations of numeracy are laid well before formal schooling starts: Positive attitudes and competencies in numeracy are essential for children's successful learning. The foundations for these competencies are built in early childhood. Curriculum implementers therefore have a responsibility to incorporate numeracy into preschool programs, but to do so in a way that is in keeping with the principles and practices of sound early childhood practice. In this research, the researcher considered how play can be incorporated in the teaching and learning to improve numeracy skills among preschool children into a play-based program and why this is so important. According to Kioko (2010) the over emphasis on the value of passing examinations; many schools in Kenya have neglected play in efforts to teach children. Pre-school teachers do not consider play as important in child numeracy learning, children are provided with little time and opportunities to play and also there are no enough play materials for the children in the learning centers. In the sub county, the children are expected to get high grades in examinations and therefore, remain in class being taught with little time for play or participate actively in learning activities. This has led to rote learning whereby the children do not understand number value, number symbols and number recognition concepts in numeracy and learning in general. It is therefore the endeavor of this research to underscore play as a cornerstone instructional component in the acquisition of numeracy skills among preschool children.

\section{Purpose of study}

The purpose of the study was to assess play determinants influencing acquisition of numeracy skills among early childhood learners in ECDE centres in Kathiani Sub County, Machakos County.

\section{The study was guided by the following objective}

To establish the forms of play used and how they influence acquisition of numeracy skills among children in preschool institutions in Kathiani sub-county. 


\section{Research Methodology}

The study utilized descriptive survey research design since it attempts to describe the characteristics of the variables of the study (Mugenda and Mugenda, 2003). The research design was applied to gather data from a wide range of respondents from pre-primary centers and entails use of questionnaires, observation checklist and interview schedules. However, equal emphasis was based on the findings of methodologies. It applied mixed methods approach, that is, quantitative and qualitative methods.

\section{Findings and Discussions}

Forms of Play and Acquisition of Numeracy Skills among Children in ECDE Center.

As per objective one, the study sought to establish forms of play and how they influence acquisition of numeracy skills among children in preschool institutions in Kathiani sub-county. Data was collected from Head teachers, ECDE teachers and learners, organized and summarized and results are indicated in table 5 and as discussed in thematic analysis of qualitative findings on how the forms of play and acquisition of numeracy skills among children.

Table 4.1 below reveals that $5.3 \%$ of ECDE teachers indicated they strongly agreed that throwing and catching helps in learning numeracy. $21.1 \%$ of ECDE teachers agreed on the statement while the majority $42.1 \%$ of ECDE teachers was undecided. $26.3 \%$ of the studied ECDE teachers disagreed with the statement and $5.0 \%$ strongly disagreed throwing and catching helps in learning numeracy skills. 
INTERNATIONAL JOURNAL OF ACADEMIC RESEARCH IN BUSINESS AND SOCIAL SCIENCES Vol. 8, No. 10, Oct. 2018, E-ISSN: 2222-6990 @ 2018 HRMARS

Table1.1: Percentage of ECDE Teachers' views on Forms of Play and Acquisition of numeracy skills among Children in ECDE Centres

\begin{tabular}{|c|c|c|c|c|c|}
\hline Skills & $\begin{array}{l}\text { S. A } \\
\%\end{array}$ & $\begin{array}{l}\text { A } \\
\%\end{array}$ & $\begin{array}{l}\mathrm{U} \\
\%\end{array}$ & $\begin{array}{l}\text { D } \\
\%\end{array}$ & $\begin{array}{l}\text { S. D } \\
\%\end{array}$ \\
\hline $\begin{array}{l}\text { Throwing and catching helps in learning } \\
\text { numeracy skills }\end{array}$ & 5.3 & 21.1 & 42.1 & 26.3 & 5.0 \\
\hline $\begin{array}{l}\text { Hoping and skipping helps children learn } \\
\text { numeracy skills }\end{array}$ & 10.5 & 26.3 & 36.8 & 10.5 & 15.8 \\
\hline Matching and pairing enhances numeracy kills & 5.5 & 10.5 & 47.4 & 31.6 & 5.0 \\
\hline $\begin{array}{l}\text { Modeling numbers helps preschool learners to } \\
\text { acquire numeracy skills }\end{array}$ & 5.3 & 26.3 & 36.8 & 21.1 & 10.5 \\
\hline $\begin{array}{l}\text { Racing games helps learners to learn numeracy } \\
\text { skills }\end{array}$ & 5.5 & 26.6 & 36.3 & 21.1 & 10.5 \\
\hline $\begin{array}{l}\text { Drawing and colouring numbers helps children to } \\
\text { enhance numeracy skills }\end{array}$ & 10.5 & 21.1 & 31.6 & 21.1 & 15.8 \\
\hline $\begin{array}{l}\text { Singing songs about numbers enhances } \\
\text { acquisition of numeracy skills }\end{array}$ & 10.5 & 31.6 & 42 & 15.8 & 0 \\
\hline $\begin{array}{l}\text { Grouping objects activity helps children to acquire } \\
\text { numeracy skills }\end{array}$ & 5.3 & 26.3 & 36.8 & 21.1 & 10.5 \\
\hline
\end{tabular}

The ECDE teacher's response on whether hoping and skipping helps children to learn numeracy, only $10.5 \%$ of the ECDE teachers strongly agreed and $26.3 \%$ agreed. Those who were undecided were $36.8 \%, 15.8 \%$ disagreed hopping and skipping helps in acquisition of numeracy and $10.5 \%$ strongly disagreed. Only $5.5 \%$ of ECDE teachers indicated that matching and pairing enhances numeracy skills and $10.5 \%$ of them agreed. $47.4 \%$ of the studied ECDE teachers were undecided, while $31.6 \%$ disagree matching and pairing enhanced numeracy and $5 \%$ strongly disagreed. Teachers who strongly agreed with modeling helps preschool learners to acquire numeracy skills were $5.3 \%, 26.3 \%$ agreed. Majority of the teachers at the rate of $36.8 \%$ were undecided whether modeling numbers helps preschool learners to acquire numeracy skills. $21.1 \%$ of the teachers disagreed and $10.5 \%$ of them strongly disagreed with the statement. The study established that the highest percentage $26.3 \%$ of preschool teachers were undecided whether racing games helps learners to acquire numeracy skills. $26.6 \%$ of them agreed and $5.5 \%$ strongly agreed. $21.1 \%$ disagreed and only $10.5 \%$ strongly agreed.

The study further established only $10.5 \%$ of ECDE teachers strongly agreed whether drawing and colouring helps children to enhance numeracy skills, $21.1 \%$ of the teachers agreed, $31.6 \%$ were undecided $21.1 \%$ disagreed and $15.8 \%$ strongly disagreed. The study revealed that majority (42\%) of the sampled ECDE teachers were undecided whether singing songs about number enhances 
INTERNATIONAL JOURNAL OF ACADEMIC RESEARCH IN BUSINESS AND SOCIAL SCIENCES Vol. 8, No. 10, Oct. 2018, E-ISSN: 2222-6990 @ 2018 HRMARS

acquisition of numeracy, $31.6 \%$ of them agreed and $10.5 \%$ strongly agreed. On contrary $15.8 \%$ of ECDE teachers disagreed with singing songs about number enhances acquisition of numeracy skills. The study further indicated that $5.3 \%$ of the sampled teachers strongly agreed that grouping objects activities helps children to acquire numeracy skills, $26.3 \%$ of them agreed whereby majority indicated they were undecided. Contrary $21.1 \%$ of the teachers disagreed and $10.5 \%$ of them were for the opinion of strongly disagree. In average the study established that (39\%) of ECDE teachers were not decided whether different forms of play enhanced acquisition of numeracy skills in ECDE Kathiani sub county.

Preschool teachers should ensure they expose learners to different play activities with variety of play materials; this arouses curiosity of the children to interact with the play materials which enhances learning of numeracy skills in a very natural way These views agree the views expressed by Essa (2011) that play provides the child with a variety of essential experiences, sensory exploration, emotional and social experiences as well as experiences of mastery or achievement. The main functions of child's play are to rehearse actions to various real-life scenarios in a safe, risk-free environment so that when confronted with a difficult situation. These views corroborate the views expressed by Wilson (2002) thatto obtain a comprehensive and optimal education in ECDE centres, we ought to employ different strategies to utilize variety of forms play including creative play, digital play, social play active play and free play. Therefore, to support the overall numeracy learning of children it is also important to adopt a variety of play based teaching and learning in preschool institutions. Play in brain development is very effective, has intellectual and cognitive benefits for the brain and it in fact shape the structural development of the brain. It is through play whereby children develop important learning and life skills such as exploring, identifying, creativity, and imagination. Introducing different forms of play into the daily learning of children not only promotes their numeracy skills but it also facilitates the most effective multi-sensory learning experience.

\section{Thematic Analysis of Qualitative Findings on the Forms of Play and Acquisition of Numeracy Skills among Children}

To get more in-depth information on the forms of play and acquisition of numeracy the head teachers were interviewed. The head teachers were asked to explain about how often ECDE teachers in their school used different types of play. The interviewees responded in favor of the view that most ECDE teachers rarely used play in teaching and learning in ECDE centres. The researcher also observed that there were very few relevant instructional activities in most ECDE centers. One head teacher noted, "ECDE teachers in my school rarely engage learners in activity lessons because play normally takes a lot of time for learners to acquire single concept or skill". These views corroborate the views expressed by Wilson (2002) that acquisition of numeracy skills and concepts calls for an imaginative approach by the teacher who needs to constantly be on alert for new ideas and techniques to make lesson presentation achieve effective outcome with different instructional activities. On the same question about explaining how often ECDE teachers in their school used different types of play another head teacher revealed that "the ECDE teachers rarely use different types of play especially during teaching and learning process due to the pressure given by parents who perceive play in school as wastage of time of their children and their money." These views indicate that there is need for the stakeholders to advocate for the importance of play in learning to both teachers and the parents. The 
intellectual and cognitive benefits of playing have been well documented. Children who engage in quality play experiences are more likely to have well-developed numerical memory skills, and are able to regulate their behaviour, leading to enhanced school adjustment. This agree with Tina (2005) who emphasizes that play is important for the early stages of brain development and playing with child can help build relationships for later life. Play helps to develop important skills for learning, life and work. This has the importance that, encouraging play is one of the key approaches that educational institutions could use to positively influence the teaching-learning process to enhance numeracy learning outcomes. The importance of play as a component in the teaching-learning process of preschool children has been underscored by educational thinkers of ancient times among them Plato and Aristotle. These educational thinkers argued that play is important in enhancing the memory and creative capacities of children.

The teachers were also asked to explain to what extent the type of play done by ECDE children in their influence acquisition of numeracy skills among children. These views thus point to the fact that use of instructional activities such as cognitive and social play helps learners improve in numeracy skills that would make learners discover facts glued firmly to the memory. The interviewees further noted, "Use of variety of instructional activities in ECDE teaching and learning arouses children's attention, sustains their interest and makes leaning to be fun". Further, these views attest to the fact that ECDE learners become motivated and stay focused. Thus, variety of activities is also important so that all children can be involved and no child is left idle during the lesson, and for them to use all their senses in learning hence develop concepts and skills. Another head teacher responded that "though in my school we have limited space for play, I know play is vital in leaning for young children. It helps learners in acquisition of new concepts and skills and also helps learners to retain them for longer." These view thus point to the fact that use of play activities develops learners' skills and concepts.

The view is consistent with the views expressed by Jean (2006) that play helps children to develop problem solving skills like simple addition, matching and pairing number value, recognition of symbols and shapes of numbers and development of the child's eye- hand coordination. Play is seen as one of the miracles of childhood by means of which children discover things essential to their wellbeing. It is part of child's life and also as a necessary condition for development.

\section{Observation Checklist for ECDE Learners and Acquisition of Numeracy Skill in ECDE Centres.}

The study sought to establish Percentage of ECDE learners' performance in observation checklist on acquisition of number symbol, number recognition and number value skills among children in your ECDE Centre. Data was observed from ECDE learners, organized and summarized as in tables 4.4, 4.5 and 4.6 below. 
INTERNATIONAL JOURNAL OF ACADEMIC RESEARCH IN BUSINESS AND SOCIAL SCIENCES Vol. 8, No. 10, Oct. 2018, E-ISSN: 2222-6990 @ 2018 HRMARS

Table 1.2: Percentage of ECDE Learners' Performance in Observation Checklist on Acquisition of Number Symbols Skill.

\begin{tabular}{|l|l|l|l|l|l|}
\hline \multirow{2}{*}{$\begin{array}{l}\text { Level } \\
\text { Performance }\end{array}$} & of & Number Symbols \\
\cline { 2 - 6 } & $\begin{array}{l}\text { Modeling } \\
\%\end{array}$ & $\begin{array}{l}\text { Mounding } \\
\%\end{array}$ & $\begin{array}{l}\text { Sticking } \\
\%\end{array}$ & $\begin{array}{l}\text { Drawing } \\
\%\end{array}$ & $\begin{array}{l}\text { Tracing } \\
\%\end{array}$ \\
\hline Excellent & 0.6 & 1.3 & 0.6 & 1.3 & 0.6 \\
\hline Very Good & 3.2 & 2.5 & 3.1 & 2.6 & 1.2 \\
\hline Good & 17.3 & 17.1 & 16.3 & 19.9 & 6.8 \\
\hline Fair & 30.5 & 30.9 & 23.1 & 17.5 & 29.1 \\
\hline Poor & 38.1 & 39.4 & 46.3 & 48.6 & 47.6 \\
\hline Very Poor & 8.3 & 6.3 & 7.5 & 8.3 & 11.4 \\
\hline Unable & 1.9 & 2.5 & 3.1 & 1.9 & 3.3 \\
\hline
\end{tabular}

Table 4.4: indicate that majority of preschool learners performed poorly (38.1\%) and fairly $(30.5 \%)$ in modeling. Only $17.3 \%$ managed to perform good, $3.2 \%$ very good and $0.6 \%$ of learners performed excellently. $8.3 \%$ performed very poorly and $1.9 \%$ was unable to perform the activity. Further the table indicates that mounting was performed poorly (39.4\%), 30.9\% fairly and $17.1 \%$ of learners managed to perform good. Those who performed very good were $2.5 \%$ and $1.3 \%$ managed to perform excellently. $39.4 \%$ of the learners performed poorly, $6.3 \%$ of the learners performed very poorly and $2.5 \%$ of them were unable. The learners who managed to perform above average in sticking were $16.3 \%$ good, $3.1 \%$ very good and $0.6 \%$ excellently. Majority performed below average at rate of $23.1 \%$ performing fairly, $46.3 \%$ performing poorly, $7.5 \%$ performed very poorly and $3.1 \%$ were unable to perform the play activity. The learners' performance in drawing was also below average. Only $19.9 \%$ of the learners managed to perform good, $2.6 \%$ managed very good and $1.3 \%$ were unable. The higher number of learners managed $48.6 \%$ poor, $17.5 \%$ fair $8.3 \%$ very poor and $1.9 \%$ were unable. Tracing activity was the most poorly performed amongst all the activities that were observed. More than $90 \%$ of learners performed fair and below. $29.1 \%$ of the performance in tracing was fair, $47.6 \%$ was poor, $11.4 \%$ was very poor and $3.3 \%$ were unable to trace numbers. Only $6.8 \%$ managed to do good and 0.6 excellent. The findings established that the number symbol performance is generally dismal in almost across all activities. Unless measures of intervention are taken to raise numeracy skills outcomes in preschools in Kathiani Sub County, the problems of poor performance levels will remain persistent.

These views further lend credence to the viewpoints held by Githinji and Kanga (2011) that a qualified teacher is expected to create the environment as well as put forth resources he/she feels are most beneficial to the child to learn how to count and classify in classroom. They further indicated that the objective of teacher training programs is to prepare and develop teachers with values, skills and knowledge required to teach competently in the preschools. Besides, teacher preparation programs need to desired attributes of beginning teachers and develop broad components of skills and knowledge with the underlying core values as the basis of the curriculum. These values, skills and knowledge articulate the desired skills and knowledge components for beginning teachers. 
INTERNATIONAL JOURNAL OF ACADEMIC RESEARCH IN BUSINESS AND SOCIAL SCIENCES Vol. 8, No. 10, Oct. 2018, E-ISSN: 2222-6990 @ 2018 HRMARS

Table 1.3: Percentage of ECDE Learners' Performance in Observation Checklist on Acquisition of Number Recognition Skill

\begin{tabular}{|l|l|l|l|l|l|}
\hline \multirow{2}{*}{$\begin{array}{l}\text { Level of } \\
\text { Performance }\end{array}$} & \multicolumn{4}{l}{ Number Recognition } \\
\cline { 2 - 6 } & $\begin{array}{l}\text { Counting } \\
\%\end{array}$ & $\begin{array}{l}\text { Colouring } \\
\%\end{array}$ & $\begin{array}{l}\text { Modeling } \\
\%\end{array}$ & $\begin{array}{l}\text { Naming } \\
\%\end{array}$ & $\begin{array}{l}\text { Identifying } \\
\%\end{array}$ \\
\hline Excellent & 1.6 & 1.4 & 0.0 & 1.3 & 0.6 \\
\hline Very Good & 2.2 & 4.3 & 2.1 & 3.6 & 2.2 \\
\hline Good & 17.3 & 17.1 & 16.3 & 15.9 & 12.8 \\
\hline Fair & 20.5 & 25.9 & 30.7 & 20.5 & 27.1 \\
\hline Poor & 48.1 & 46.3 & 49.3 & 48.6 & 49.6 \\
\hline Very Poor & 7.3 & 2.5 & 7.5 & 8.5 & 6.4 \\
\hline Unable & 2.9 & 2.5 & 4.1 & 1.7 & 1.3 \\
\hline
\end{tabular}

Table 4.5: indicate that majority of preschool learners performed poorly (48.1\%) and fairly (20.5\%) in counting activity. Only $17.3 \%$ managed to perform good, $2.2 \%$ very good and $1.6 \%$ of learners performed excellently. 7.3\%performed very poorly and $2.9 \%$ was unable to perform the activity. Further the table indicates that colouring was performed poorly $(46.3 \%), 25.9 \%$ fairly and $17.1 \%$ of learners managed to perform "good". Those who performed very good were $4.3 \%$ and $1.4 \%$ managed to perform excellently. $46.3 \%$ of the learners performed poorly, $2.5 \%$ of the learners performed very poorly and $2.5 \%$ of them were unable. The learners who managed to perform above average in modeling were $16.3 \%$ good, $2.1 \%$ very good and $1 \%$ excellently. Majority performed below average at rate of $30.7 \%$ performing fairly, $49.3 \%$ performing poorly, $6.5 \%$ performed very poorly and $4.1 \%$ were unable to perform the play activity. The learners' performance in naming was also below average. Only $15.9 \%$ of the learners managed to perform good, 3.6\% managed very good and $1.3 \%$ managed to perform excellently. The higher number of learners managed $48.6 \%$ poor, $20.5 \%$ fair $8.5 \%$ very poor and $1.7 \%$ were unable. Majority of preschool learners performed poorly (49.6\%) and fairly $(27.1 \%)$ in identifying activity. Only $12.8 \%$ managed to perform good, $2.2 \%$ very good and $0.6 \%$ of learners performed excellently. $6.4 \%$ performed very poorly and $1.3 \%$ was unable to perform the activity. The findings indicated that preschool learners in Kathiani Sub County performed poorly in number recognition activities which help to enhance acquisition of numeracy skills. It is crucial for the preschool teachers to follow the curriculum, introduce use of appropriate activities as they are indicated in the ECDE syllabus hand book to prepare schemes of work and lesson plans to enhance acquisition numeracy skills. It is also important to remark after every lesson and follow up for the activities which are poorly performed.

These findings corroborate the assertions of Sandlie (2013) emphasized the importance of training ECDE teachers as he observed that most of ECDE centers in Kenya emphases academic and give little or no time for learners to get actively involved in teaching and learning activities. The trained teacher has to endeavor first and to understand that world organize it in the most rational way possible and present it to the learner. This view may still engage the teacher in providing the learner with activities with hand-on learning with opportunities to experiment and manipulate the objects of the world but the intention is always to make it clear to the learner the structure of the world independent of the 
INTERNATIONAL JOURNAL OF ACADEMIC RESEARCH IN BUSINESS AND SOCIAL SCIENCES Vol. 8, No. 10, Oct. 2018, E-ISSN: 2222-6990 @ 2018 HRMARS

learner. These findings thus point to the fact that a teacher is expected to create the environment as well as put forth resources he/she feels are most beneficial to the child to learn how to count numbers, identify numbers, name numbers, color and draw numbers in learning activities.

Table1.4: Percentage of ECDE Learners' Performance in Observation Checklist on Acquisition of Number Value Skill.

\begin{tabular}{|l|l|l|l|l|l|}
\hline \multirow{2}{*}{$\begin{array}{l}\text { Level of } \\
\text { Performance }\end{array}$} & \multicolumn{4}{l}{ Number Value } \\
\cline { 2 - 6 } & $\begin{array}{l}\text { Sorting } \\
\%\end{array}$ & $\begin{array}{l}\text { Arranging } \\
\%\end{array}$ & $\begin{array}{l}\text { Grouping } \\
\%\end{array}$ & $\begin{array}{l}\text { Matching } \\
\%\end{array}$ & $\begin{array}{l}\text { Pairing } \\
\%\end{array}$ \\
\hline Excellent & 1.9 & 1.3 & 1.9 & 0.6 & 1.3 \\
\hline Very Good & 1.9 & 3.2 & 1.9 & 4.5 & 2.6 \\
\hline Good & 16.1 & 16.5 & 15.5 & 16.1 & 14.4 \\
\hline Fair & 20.6 & 25.1 & 28.7 & 21.6 & 23.5 \\
\hline Poor & 45.8 & 39.7 & 35.8 & 41.0 & 45.3 \\
\hline Very Poor & 12.3 & 13.5 & 14.2 & 12.9 & 11.0 \\
\hline Unable & 1.3 & 0.6 & 1.9 & 3.2 & 1.9 \\
\hline
\end{tabular}

Table 4.6: reveals that (45.8\%) the highest percentage of learner's performance in sorting was poor, followed by $20.6 \%$ who performed fairly. $1.9 \%$ of learners performed very poorly and 1.3 were unable to sort. Learner performed poorly $39.7 \%$ and $25.1 \%$ fairly. Only 16.5 performed good $3.2 \%$ very good and $1.3 \%$ performed excellently. $13.5 \%$ of learners performed very poorly and $0.6 \%$ were unable. Most of learners in grouping performed poorly $35.8 \%$ and fairly $28.7 \%$. 15.5\% performed Good, $1.9 \%$ Very good and $1.9 \%$ excellently. $14.2 \%$ of learners performed very poor while $1.9 \%$ were unable. Matching was also performed poorly 41\%, 21.6\% performed fairly. 16.1\% managed to perform good $4.5 \%$ very good and 0.6 excellently. $12.9 \%$ of learners performed very poor and 3.2 were unable to match. In pairing performance $45.3 \%$ learners performed poorly $23.5 \%$ fairly, $14.4 \%$ good $2.6 \%$ very good and $1.3 \%$ performed excellently $11.9 \%$ performed very poor and $1.9 \%$ were unable to perform the pairing activity. It is noted with a lot of concern that efforts to improve learning outcomes of number value skills should be focused in Kathiani Sub County preschool institutions due to the poor performance established from the observation checklist on acquisition of number value skills.

Just like in quantitative findings, these views further corroborate the views expressed by Margaret (2009) who emphasis on the importance of play as she observed that most ECDE centers in Kenya emphases academic and give little or no time for learners to interact with instructional materials. He further observed that in Kenya pre-school children are subjected to academic work due to pressure from parents who would like to see their children read and write within weeks upon joining preschool. The ECDE curriculum developed by K.I.E has the provision for learners to interact with instructional materials but this is overlooked by parents and private school managers who insist that the pre-school children have to be taught numeric, literacy and have the ability to read and write this fact is compounded by the fact that the primary school head teachers subject the ECDE children with oral and written interview for them to be admitted to standard one hence gives no room for learners to learn through doing. 
Play is one of the main ways in which children learn. It helps to build self-worth by giving a child a sense of his or her own abilities and to feel good about themselves and worth. Because it's fun, children often become very absorbed in what they are doing. In turn, this helps them develop the ability to concentrate. Providing children with a range of playthings will help them to acquire numeracy skills. In addition, most children are naturally imaginative and will happily talk away to someone on their toy phone or drive the sofa to the shops, and this creativity should be actively encouraged. Play activities develops children's imaginations which are closely linked to intellectual development. It's important that learning to be made fun at preschool age that is, it needs to be about doing things with them that they like. For instance, Hoping and skipping helps children learn early introduction to numeracy skills like learning that counting while hoping or skipping, building blocks, jigsaws and shape sorters can help with recognizing different shapes and sizes, putting things in order and developing logic, drawing and painting numbers, play activities can encourage creativity, imagination and expression of feelings. Just like in quantitative findings, these views further corroborate the views expressed by Kioko, (2010) who stresses that teachers in pre-schools are expected to play with children, teach them alphabet and numerals and make them be aware of their cultural patterns through play, storytelling or music activities. This study holds that intervention measures towards raising learning outcomes need to start from the early formative stages, that is, from preschool to the rest of the educational levels, thus need to focus on the acquisition of numeracy skills among preschool children. Generally, the study established that (48.8\%) learners performed poorly in number symbols activities, $48.4 \%$ performed poorly in number recognition activities and $41 \%$ in number value activities.

\section{Recommendations for Practice}

The study makes the following recommendations:

i On forms of play, the study recommends to county government through DICECE that seminars, conferences and workshops should be organized to sensitize ECDE teachers to understand that use of play is educational components which serve to enhance teaching and learning of numeracy in ECDE centers.

ii KICD need to advocate and strategize on provision of variety of teaching and learning materials that encourages use of different forms of play to enhance acquisition of numeracy skills among children in ECDE centers.

iii The study recommends that ECDE teachers should remain constant learner on issues pertaining children education and development and also training on usage of different forms of play as teaching component in ECDE centers. Teacher training colleges should focus more on units that equip teacher on psychology of children and on how children learn. The school stakeholders should also ensure that the teachers employed in the preschool have the required training and experience to handle the preschool learners. These teachers should also be motivated to go overboard, in enhancing the learning and performance of the learners through use of different forms of play.

iv The Ministry of Education, Science and Technology should enforce the usage of variety of play as a critical component of pedagogy in ECDE centers. It should also support ECDE Programme by implementing preschool teachers' terms of service. 
INTERNATIONAL JOURNAL OF ACADEMIC RESEARCH IN BUSINESS AND SOCIAL SCIENCES

Vol. 8, No. 10, Oct. 2018, E-ISSN: 2222-6990 ㄷ 2018 HRMARS

\section{References}

Best, R. \& Kahn, H. (1993). Managing to learn: Aspects of reflective and experiential learning in schools. Continuum International Publishing Group.

Creswell, J., Plano Clark, V. Guttmann, M. \& Hanson, W. (2003). Advanced mixed methods research designs. Handbook of mixed methods in social and behavioral research, 209240.

Debra, J. (1982).Play of Children's Current Theory. Maldem Blackwell Publishers U.S.A.

Essa, F. (2011).Early childhood care, growth and development: Nairobi, Kenya: UNICEFEastern and Southern Africa Regional Office

Eva, L. (2011).Early childhood Education 3rd Edition, Delma Publishers, New York.

Gale, N. (2005).Encyclopedia in Children's Health, Cangage Publishers Amazon U.K.

Gay, L. (2003).Education research, Competence for Analysis and application ( $7^{\text {th }}$ Edition) Upper Saddle River: Merill Prentice Hell.

Githinji, F. \& Kanga, A. (2011). Early childhood development education in Kenya: A literature review on current issues. International Journal of Current Research

Hendrick, J. (1992).the whole child, 5th Edition Macmillan, New York.

Jean, T. (2006). Workbook with Movable Colored Clips, GarsonDelosa Publishers Company Amazon U.K.

Joel, F. (2010).Play and Play Environments, Rootledge Publishers, New York London.

Jolly, P. (1977).Book of child care, Sphere book Limited, New York.

Kabiru, M. (1993). Early childhood care and development: A Kenyan experience. Nairobi, Kenya:

UNICEF Eastern and Southern Africa Regional Office

Kang'ara H. (2017). Influence of teachers' instructional practices on learning of pre-school

Children in Kiambu West Sub-county, Kiambu county, Kenya: Unpublished PhD thesis, Mount Kenya university

Karen (2007). the child care professional Volume1, Glencore, McGrew-Hill

Kenya Institute of Education (1994).how children grow and develop, Kenya Literature Bureau, Nairobi

Kenya Institute of Education (1997). Pre- school Activity book III, Kenya Literature Bureau, Nairobi.

Kenya Institute of Education (2008). Syllabus for Pre- school, Kenya Literature Bureau, Nairobi.

Kioko, (2010). Play and child learning, Kenya Literature Bureau; Nairobi

Kothari, C. (2004).The research methodology: Method and techniques $4^{\text {th }}$ Edition, New Delhi, New international Publication Limited.

Kutner, L. (2008).What Parents cando, Simon and Schaster Publishers. New York.

Leach, P. (1989). Baby and Child, Penguin Group, 27 Wring Lane, London.

Lundreth (2015). Better Kids Care. Twinfalls Publishers Philadelphia.

Machakos County Integrated Plan (2015). Machakos County

Margaret M, (2009). Little Birds ECDE Teacher Education. Mathematics Activities Sasa

Semaprint of Longhorn Publishers Nairobi Kenya.

Margaret. N. Kabiru, Anne W. (2007). Child Development. Focus publishers LTD. Nairobi

Kenya. 
INTERNATIONAL JOURNAL OF ACADEMIC RESEARCH IN BUSINESS AND SOCIAL SCIENCES

Vol. 8, No. 10, Oct. 2018, E-ISSN: 2222-6990 ㄷ 2018 HRMARS

Merriam (1998).methods of research, Rennis and Tyaster Publishers: New York.

Ministry of Education, Science and Technology, (2005). Sessional paper No. 1 of 2005, on A Policy Framework for Education, Training and Research. Kenya Education

Mugenda O. \& Mugenda. (2003).Research method: Qualitative and Quantitative approaches. Nairobi: Kenya.

NACECE (2001). Play and child learning in Kenya: Kenya Literature Bureau, Nairobi.

Orodho, A. J. (2003), Essentials of Education and social science research methods. Nairobi. Kenya: Pauline Publishers.Orodho, A. (2012). Techniques of writing research proposals and reports. Nairobi: Kanezja H P Enterprises.

Sandlie, B. (2013).child play: Little Filed Publishers: New York.

Sifuna D.N. \& Otiende J. E (1995). Introductory history of Education. Nairobi: University of Nairobi press.

Syomwene, A. (2013). Factors Affecting Teachers' Implementation of Curriculum Reforms and Educational Policies in Schools: The Kenyan Experience. Journal of Education and Practice, Vol.4(22), 80-86.

Retrievedfrom; http://www.iiste.org/Journals/index.php/JEP/article/viewFile/8330/8666

Tina, B. (2005). Early Childhood education and development, Hodder Educational Publishers. U.K.

Vygosky, L. (1978).Early Childhood class management and social interaction: Maldem Blackwell Publishers U.S.A.

Wilson, D. (2002). Relevance theory. Handbook of pragmatics. 